Canadian University Music Review

Revue de musique des universités canadiennes

\title{
Medieval Polyphony in a Cividale Manuscript
}

\section{Bryan Gillingham}

Numéro 6, 1985

URI : https://id.erudit.org/iderudit/1014038ar

DOI : https://doi.org/10.7202/1014038ar

Aller au sommaire du numéro

\section{Éditeur(s)}

Canadian University Music Society / Société de musique des universités

canadiennes

\section{ISSN}

0710-0353 (imprimé)

2291-2436 (numérique)

Découvrir la revue

Citer cet article

Gillingham, B. (1985). Medieval Polyphony in a Cividale Manuscript. Canadian University Music Review / Revue de musique des universités canadiennes, (6),

239-255. https://doi.org/10.7202/1014038ar

(c) Canadian University Music Society / Société de musique des universités canadiennes, 1985
Ce document est protégé par la loi sur le droit d'auteur. L'utilisation des services d'Érudit (y compris la reproduction) est assujettie à sa politique d'utilisation que vous pouvez consulter en ligne.

https://apropos.erudit.org/fr/usagers/politique-dutilisation/ 


\title{
MEDIEVAL POLYPHONY IN A CIVIDALE MANUSCRIPT
}

\author{
Bryan Gillingham
}

Cividale del Friuli, a small town situated Northeast of Venice not far from the Yugoslavian border, is endowed with great natural beauty - it is surrounded by mountains skirted below with vineyards and built on the walls of a canyon carved out by a green river. It also boasts a rich archeological museum which houses sculptures and many other artifacts dating as far back as the time of Julius Caesar (who once passed through the town) and beyond. In addition, the museum includes an extensive library of medieval manuscripts, many of which contain music. Its books are not easily studied, partly because of the remote location of the town, and partly because the Museo Archeologico provides neither microfilm nor xerox copies of its treasures. The purpose of this brief study is to make available the polyphony in one of its manuscripts, Cividale del Friuli, Museo Archeologico Nazionale, Codex LVII, hereafter referred to as I-CF57 (see Fischer and Lütolf 1972: B IV/4, 746-47). This manuscript is an extensive antiphoner which was once used in the cathedral at Cividale. It is thus predominantly monophonic in nature, but it does include four polyphonic compositions - two two-voiced sequences and two three-voiced hymns - of special interest to us here.

Beyond this manuscript, the greater polyphonic repertory of Cividale has been classified broadly into three sets or categories: "primitive" polyphony of two voices intended for use in the liturgy; Ars Nova compositions by such composers as Antonius da Cividale, Rentius de Ponte Curvo, Philippus de Caserta, Jacob de Senleches, and Zachara da Teramo; and a third group of pieces by renaissance composers such as Josquin, Mouton, Willaert, Claudin de Sermisy, and others (see Petrobelli 1956:213-15 and 1980:423). Whereas the first two examples from I-CF57 belong clearly to the 
first category, the other two are really on the fringes of the Ars Nova repertory, not being quite the same in nature as the music of those composers mentioned above; the latter two foreshadow or duplicate trends evident in the period of Dufay. As far as can be determined, none of the four is available in modern edition.

The four polyphonic works in this leatherbound antiphoner of 362 folios are distributed randomly amidst the large quantity of monophony. Although I-CF57 was probably compiled in the late fourteenth or early fifteenth century, a portion of its contents was initially composed centuries earlier. The first two polyphonic pieces (Exx. 1 and 2, both of which predate the manuscript) reflect the prevailing characteristics of the non-mensural square notation, but the other two (Exx. 3 and 4) are mensurally notated and are clearly later additions to the manuscript. The first two employ color coding - red (non-mensural) and black notation to distinguish the two voices - and perhaps reflect earlier Paduan influences. ${ }^{1}$ The three-voiced compositions are recorded in a black Ars Nova notation, devoid of the ars subtilior indulgences. While the four pieces to be discussed do not qualitatively or quantitatively reflect the prevailing nature of I-CF57, each of them merits comment on account of certain peculiar features.

The first of the four, Missus ab arce veniebat (Ex. 1), judging from the rubric "Prosa super tamquam sponsus" which appears at the top of the composition, is a prose or sequence - but if so, it is a rather unusual one. Normally, polyphonic sequences from the period of their inception into the Western tradition centuries earlier, would unfold in a series of at least three or more double versicles. In this case, a single versicle in two voices is followed by a monophonic versus to the text of the antiphon Tamquam sponsus. ${ }^{2}$ The first part of this melody, the melisma over the tamof tamquam, duplicates the upper part of the polyphonic versicle, then launches into an expansive monophonic setting of the antiphon, thus breaking away from the successively repetitive norms of sequence writing. This appears to be a free adaptation of the troping process rather than a sequence proper. Furthermore, the whole musical process is repeated immediately thereafter in a "Prosa super Gloria patri," 3 a contrafactum of the preceding "prose." Rather than a sequence, we are apparently presented with an antiphon trope followed by a doxology trope. It is unclear as to whether the two would be performed at the same time (in succession) or as separate entities on different occasions.

The original notation of Example 1 consists of square notes, ex 
omnibus longis, which is not unusual for sequences, but the use of red longs to distinguish the parts is. In the transcription the black notes are put on the upper staff and the red notes on the lower; although the voices cross a number of times and could be switched, the upper is likely the principal one since it is repeated in the versus. The text throughout is not characterized by the balance and symmetry common in post-eleventh-century sequences and gives no hint that it should be metrically interpreted. The imbalance, along with the lack of rhyme, and because of the extensions in the contrafactum, suggests a non-mensural interpretation of rhythm. If this is to be considered a sequence, it is out of step with mainstream developments; this is perhaps explained by the remote location of Cividale and possible lack of contact with developments elsewhere. In any case, it is better considered an addition to something preexistent, a sense in which the term "prosa" is sometimes used (see Kelly 1977:366-90).
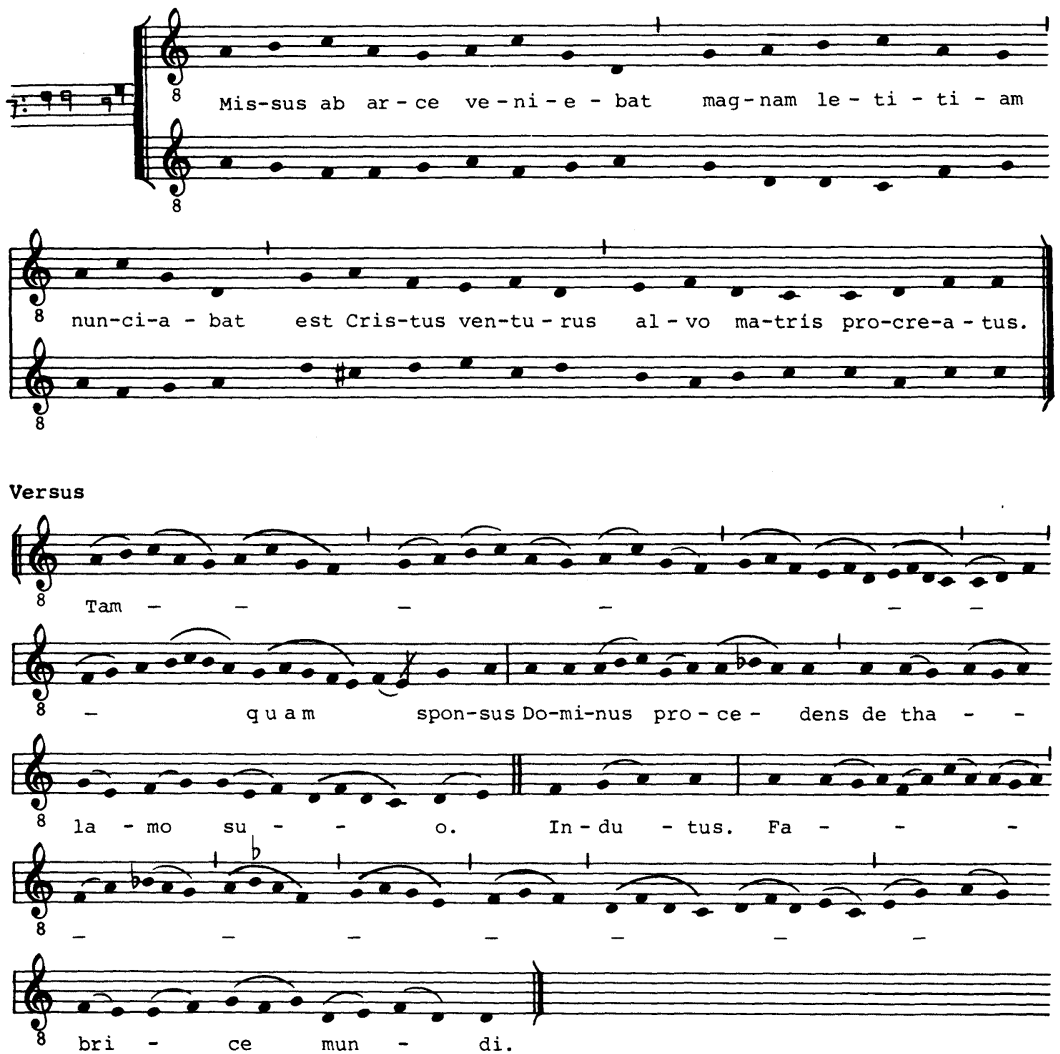


\section{2}

Prosa super gloria patri
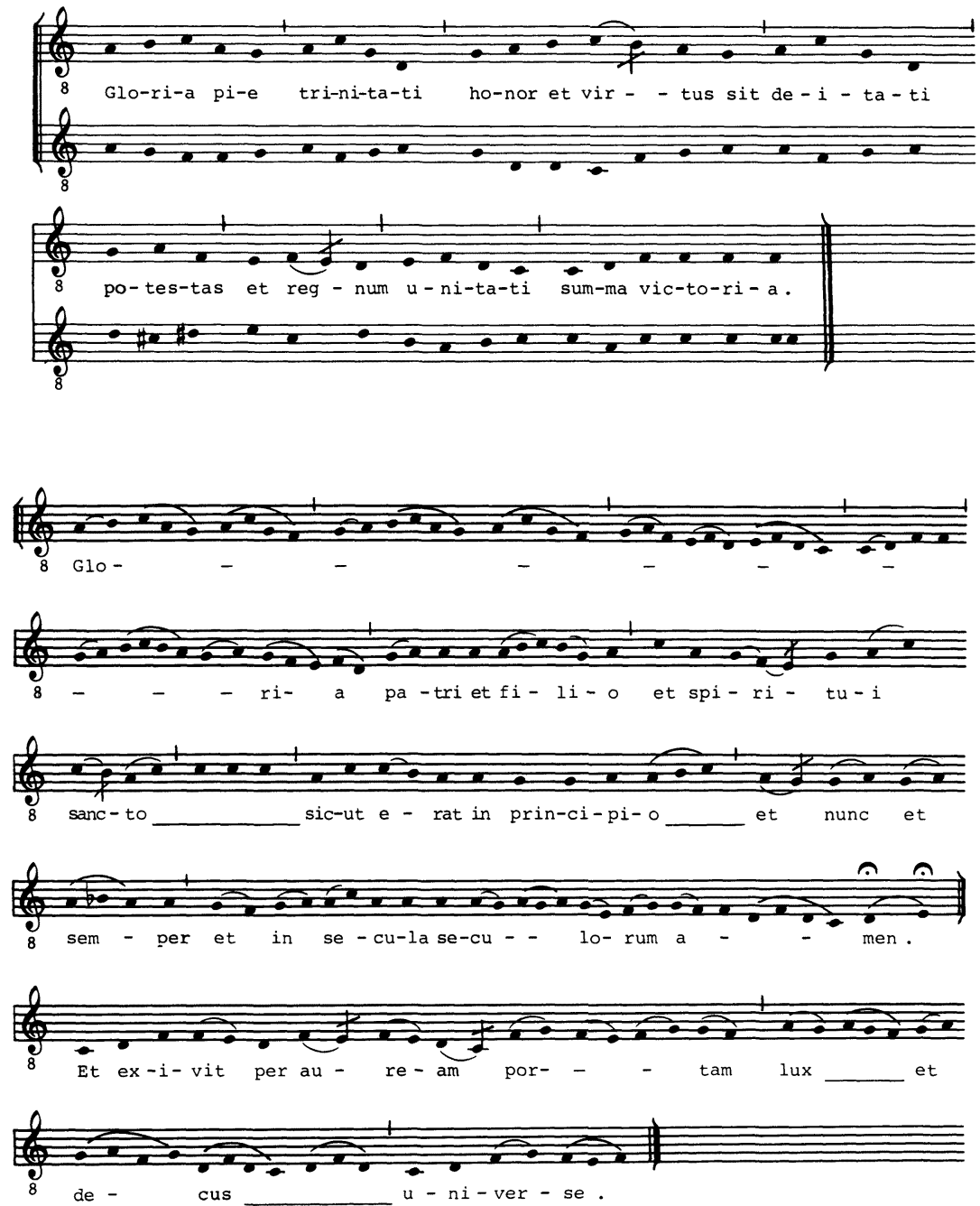

Example 1

Quem ethera et terra (Ex. 2) resembles Example 1 in its notational methods (ex omnibus longis in red and black) and in some passing stylistic features, but it differs in format, and what is more important, offers rare yet specific information on performance practice. Formally, Quem ethera unfolds in an orthodox manner for the sequence (progressive double versicles), but it does 
alternate monophony and polyphony as in the previous example, albeit in a more structured manner. In this case the monophony is less protracted and not underlaid with text. The implication is that the syllable "E" should be vocalized in a kind of cauda to the half versicle preceding. The "E" could indicate such a vocalization or it could be an abbreviation for "Eadem," thus indicating a repeat of the same words that preceded it; or it could perhaps indicate a word such as "Emmanuel" found in the text or some other such word. In any case, the resultant form involves fourfold repetition linked with alternatim between polyphony and monophony. The alternation of musical textures is emphasized by an associated method of performance, or performance forces, which are specified. The rubric at the top states: "Dicta repeticione dicatur sequens prosa et dicatur in choro chorarii" (I-CF57:f. 28v.). This rather redundant and unclear directive tells us, apparently, about repetitions, chorus, and soloists. Its meaning is clarified by the words "chorus" and "chorarii" inserted throughout the music (reproduced on Ex. 2). The "chorarii" were likely soloists; the "chorus" perhaps a larger, less skilled group of singers. Soloists, therefore, would initiate each versicle with a polyphonic duet, followed by the choir which would repeat what it had heard in a simpler monophonic style. It is impossible to say whether this method for performing a sequence was peculiar to Cividale, or symptomatic of a more general performance practice. This particular sequence, with its asymmetrical text and unbalanced structure, had been known elsewhere in Europe long before its inclusion in the Cividale manuscript. ${ }^{5}$ The manner of performance, spelled out here, at the least offers a potential alternative to more condensed or uniform presentations.

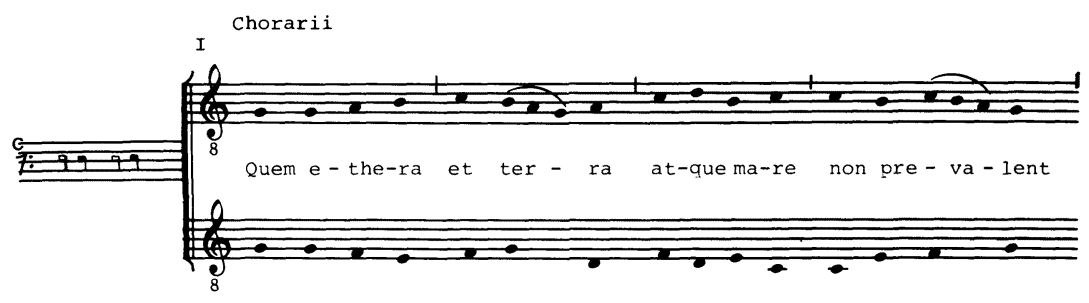

Chorus

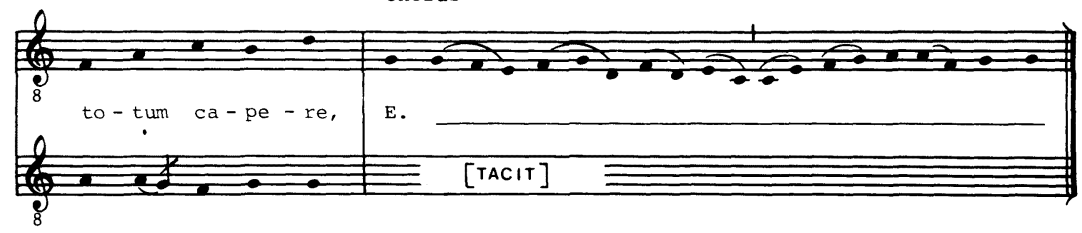


Chorarii

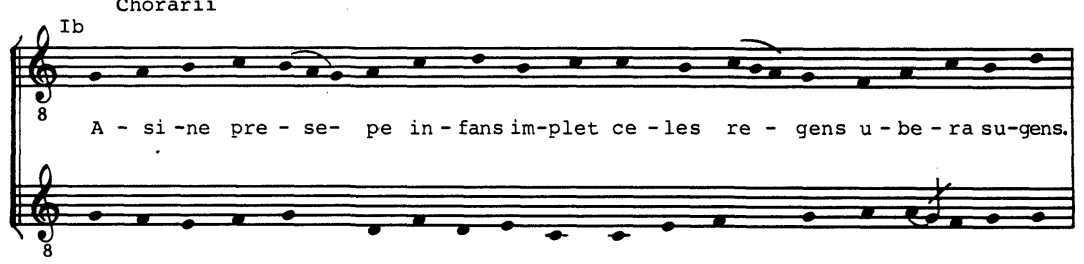

Chorus

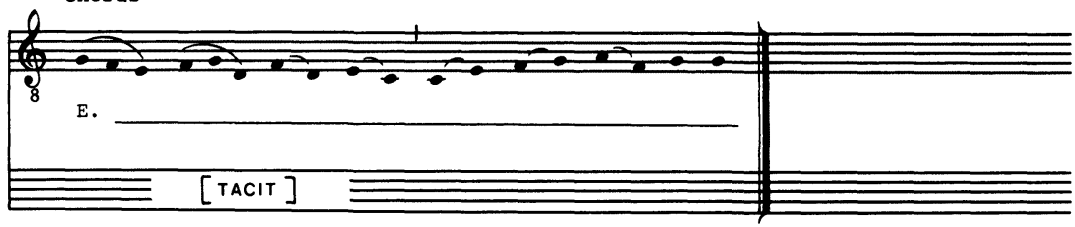

Chorarii
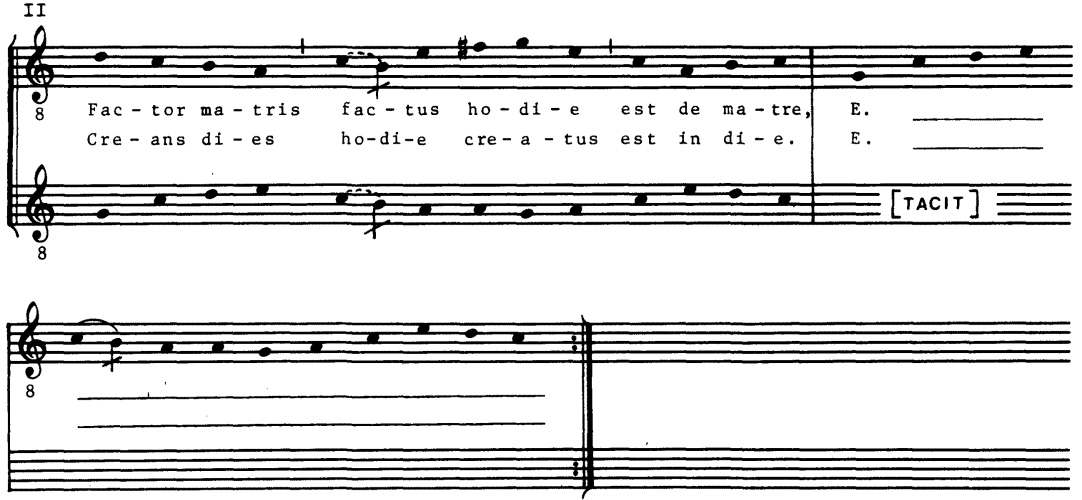

Chorarii

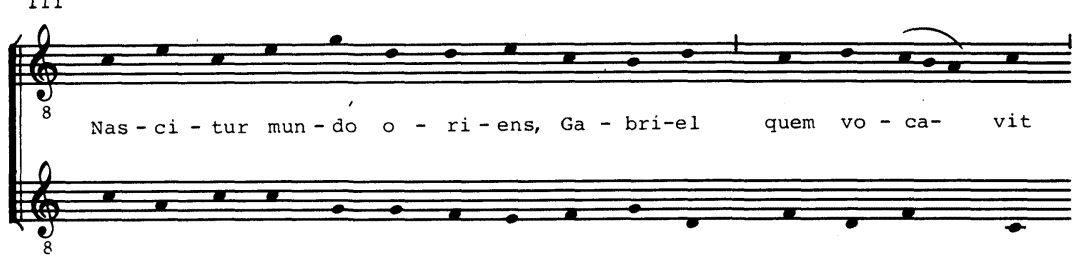

Chorus

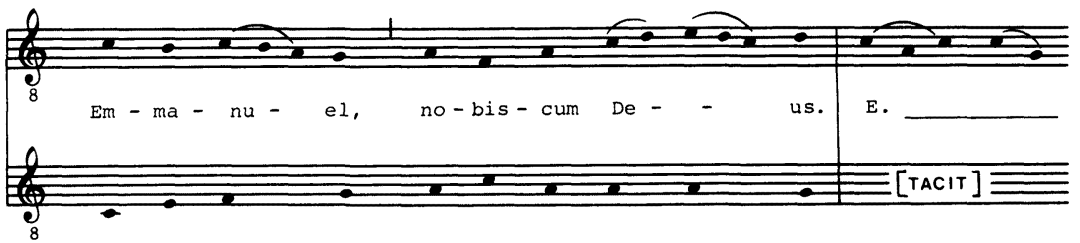




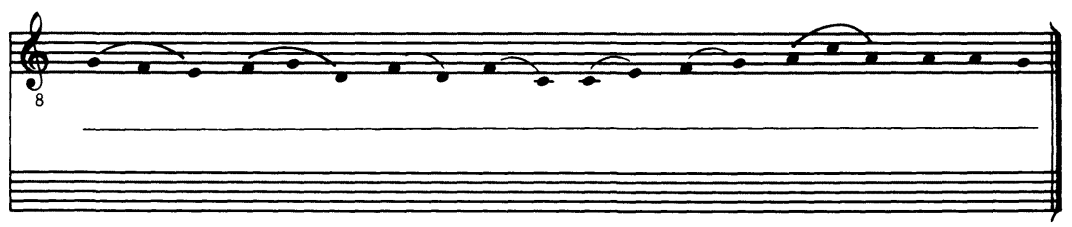

Example 2

While the first two polyphonic items in I-CF57 belong to the sequence orbit, the other two are hymns. The latter do not have concordances in the repertory of Cividale as the sequences do, though they are to be found in manuscripts from other centers. The history of the hymn, needless to say, stretches back to Ambrose and antiquity, insofar as monophonic settings are concerned. However, "except for a few isolated examples such as the famous voice-exchange hymn found with a number of texts in sources up to $1400 \ldots$ the history of the polyphonic hymn properly begins with the group of ten settings for three voices in the Apt manuscript (F-Apt 16 bis)" (Ward 1980a:841). The Apt manuscript was probably composed for the papal court at Avignon in the last quarter of the fourteenth century and its contents undoubtedly touched some of the Italians working there. Furthermore, fragments from music of Philippus de Caserta, Jacob de Senleches, and Zachara da Teramo in various manuscripts from Cividale may be associated "with the presence in Cividale of the papal court and of the council in 1409" (Petrobelli 1980:423). This direct connection between Avignon and Cividale at about the same time as the recording of the two hymns discussed below, perhaps helps to explain their inclusion in a rather different repertory, their provenance, and their approximate date.

The two hymns share certain obvious characteristics - they are about the same length, both only record in the manuscript a single stanza of a longer poem, and both are for three voices. A number of subtle distinctive qualities in each, however, merits closer scrutiny. In several ways, the first of these, Letare felix Civitas (Ex. 3) is the more unusual of the two. Recorded in a notation quite different from that prevailing in the manuscript, it is obviously a later addition in what appears to be a more refined French Ars Nova script. The noteheads are exclusively black; with stems as needed they create a mixture of Longs, Breves, Semibreves, and Minims. The complete piece is on a single page (f. 308 r) with the two upper voices positioned side by side above the 
tenor which in turn extends the full width of the folio. Though the music is carefully recorded for the most part, there are a few erasures and corrections in the top voice and the underlay (all voices are texted) is somewhat casual. Since in I-CF57 only the initial verse of text appears, the remaining strophes ( 2 to 8 ) are here supplied from Analecta Hymnica (Dreves, Blume, and Bannister 1886-1922:XXII,89). According to this textual edition, the object of the poem is St. Donatus ("De Sancto Donato"), and the text survives in at least one other manuscript from the fourteenth century (see Dreves, Blume, and Bannister 1886-1922:XXII,89), but is rarely to be found in other hymnaries. ${ }^{6}$ In spite of its rarity, the text is couched in the familiar Ambrosian format $[8 / 8 / 8 / 8$ strophes); this polyphonic setting is unique, as far as can be determined.

There are a few hints in the poetry of Letare felix Civitas as to its place of use, purpose, and possible authorship. The word "Civitas" in the opening line may refer to Cividale itself in which case the hymn could be considered a local manifestation. It has not been possible for the present writer to establish a peculiar significance for St. Donatus in Cividale, but

... the use of a proper text for the feast of a particular saint instead of texts drawn from the Common of Saints indicates special veneration and can be an important clue helping to determine the origin of a manuscript (Ward 1972:173).

The matter of St. Donatus's importance to Cividale can be left open for the moment, but we can at least determine which of several historical figures by that name is the one intended. Some possible candidates are: Donatus, the North African schismatic who was not really a saint (see Faul 1967:1003); St. Donatus, Bishop of Arezzo (fl. A.D. 362), a martyr under Julian the Apostate, sometimes confused with the Bishop of Euroea (see Butler 1963:III,275); St. Donatus of Besançon (d. ca. 660), who established the cloister of St. Paul in that city, assisted at various councils, and wrote a Regula ad virgines (see Faul 1967:1003); and finally, St. Donatus, Bishop of Fiesole (fl. ca. 876), an Irish monk who became bishop of that town and had some skill as a poet (see Butler 1963: IV,178). This is indeed a confusing array of Donati! The Donatus referred to in the poem must be the last-mentioned - Donatus of Fiesole. This is strongly implied in stanza 2 where his name is linked with that of St. Romulus, an apostle who flourished towards the end of the first century, who, according to legend, was 
brought up by a wolf, and most important, who became the first Bishop of Fiesole (see ibid.:III,22). Although we can be quite certain that the Donatus referred to is the saint of Fiesole, it is not quite as clear as Analecta Hymnica suggests that the poem is directed to him alone, nor is his status in Cividale clear. Since Fiesole is closer to Cividale than any of the centers associated with other Donati, or the other saints in the poem, it is to that city we should look for the origins of the hymn.

Unlike the other polyphonic pieces in I-CF57, Letare felix Civitas has a word beside it in the right hand margin, which apparently does not relate to the poetry, and which could be a name. This casually written, abbreviated word appears to read mechu, but each of the symbols in it could be construed in several ways: the initial letter could be an ' $n$ ' or ' $m$ '; the 'e' could be an abbreviated 'ae' or possibly 'a'; the 'c' could be a ' $t$ '; the crossed ' $h$ ' could be interpreted in several ways ('he', 'hi'); and the 'u' could also be two 'i's. The possible permutations and combinations are numerous, and when linked with other information, could lead to outrageous speculations. For example, the style of the piece is strongly reminiscent of Machaut (recurrent rhythmic cells, texture, syncopation, double-leading-note cadences) as the ascription in the margin resembles his name; yet he is not likely the composer of the piece in spite of its French notational and stylistic flavor. He is not known ever to have written a polyphonic hymn, let alone one for Fiesole. Another possible composer is Matteo da Perugia (d. ca. 1418). He and his acquaintance Filargo (who taught at the Sorbonne in the late fourteenth century) were thoroughly versed in the French culture centered at Avignon; "... there is no doubt that both of them considerably abetted the growth of French culture in northern Italy" (Günther 1980b:829). Though Fischer and Gallo do not exclude the possibility that Letare felix is by Matteo, they do not include it as one of his creations (1976:188). The ballades, virelais, and rondeaux of that composer (see Apel 1950:1-22), display elaborate mannerisms which are not a feature of Letare felix. This rather emphatic stylistic difference casts doubt on the piece's authorship by Matteo. Another possible composer is Melchior de Brissia or Prepositus Brixiensis (fl. 141125 in Padua), often confused with Mattheus de Brixia (fl. 1412-19), a canon of Vicenza cathedral.7 Finally, one Matheus de Sancto Johanne (fl. 1365-89), a successor of Machaut who served as capellanus at the papal private chapel in Avignon, is another possible composer (see Günther 1980a:820). The active period of 
this last composer, plus his affiliations with Avignon (and by extension, possibly Cividale) would certainly qualify him as a potential composer. However, none of the above can be definitely confirmed or ruled out as the possible composer. Letare felix, nonetheless, stands as one of the earliest examples of the polyphonic hymn. It draws together French and Italian elements in such a way as to point to Avignon as the possible place of origin, or at least, inspiration.
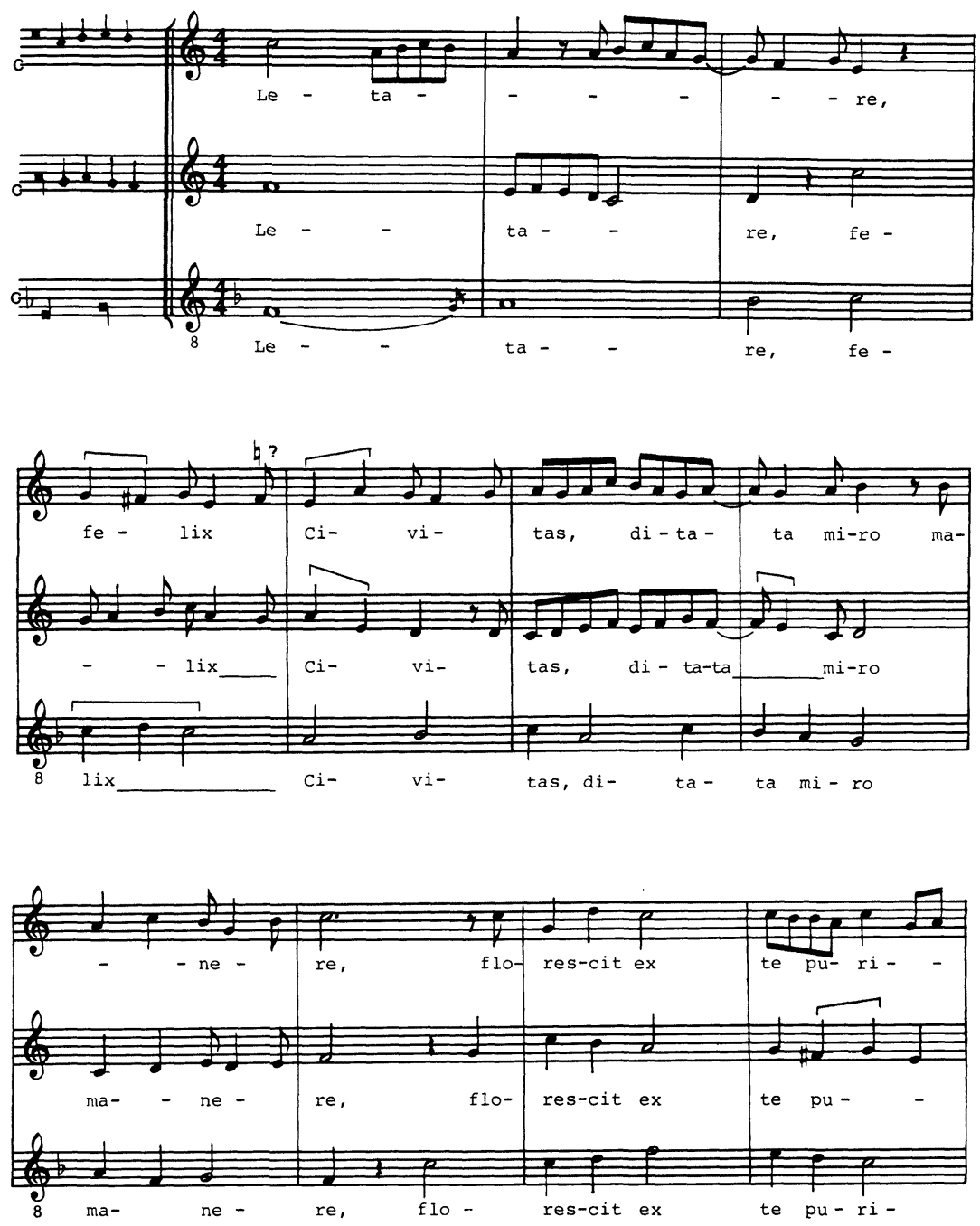


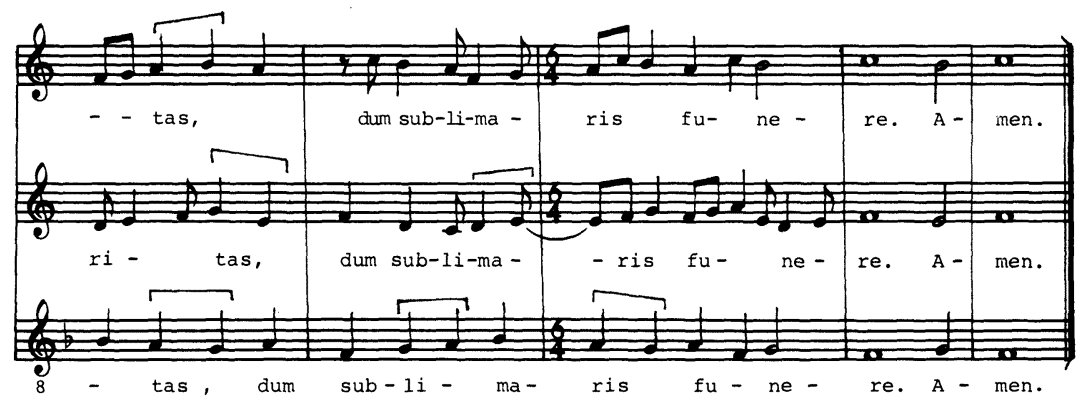

[2. Tantorum patrum hodie Donati atque Romuli, Quorum laudes ecclesiae, Cuncti extollant populi.

3. O vir Dei Hermogenes, Martyr sancte, pretiose, Summi regis sceptra tenes Congaudendo gloriose.

4. In coelesti collocatus Aeterni Dei solio, Nostros hic dele reatus Nosque commenda filio.
5. His adjunctus est Silvanus Et Venustus passione, Hos truncat Victorianus Superatus in agone.

6. Patronorum civitatis Hujus, sacratae sanguine Et mundatae caecitatis Haereticorum semine,

7. Dies ergo iste laetus Venerando veneretur; Laudes dicat noster coetus, Ut laudando societur.

8. Deo patri ingenito, Jungatur sine macula Spiritui paraclito In sempiterna saeculo.]

\section{Example 3}

The fourth polyphonic composition in I-CF57, Iste confessor (f. 326), ${ }^{8}$ is a more common hymn of the period than Example 3, since it is to be found in a number of manuscripts with differing musical settings. Example 4 is in a cruder hand than the other hymn (there is some carelessness with note and rest values), the lowest voice appears to be in a hand distinct from the upper two, and the notation is more Italianate (the dot of division is used for rhythmic organization). The numerous "concordances" vary in degree of textual and musical fidelity to this version: some are close, some remote. In Stäblein's extensive monophonic hymn collection there are fifteen melodies listed for this text (1956:671); some of these are clearly related to, but none is exactly like, the 
tenor of Example 4. A loosely similar text, and melody with affiliations to the upper part is to be found in the Liber Usualis (Benedictines of Solesmes 1962:1177). Yet the parallels between Example 4 and some available polyphonic versions are closer than those to the monophonic sources. One of the closest concordances is to be found in the celebrated Apt manuscript ${ }^{9}$ which includes "... a principal part of the surviving repertory of the Avignon papal court (1377-1417)" (Günther 1980c:663). The Apt version is nearly identical to Example 4 except in its inner voice which is less active. A two-voiced concordance (B-T190, f.29) employs the tenor of Example 4 as an upper voice in a late fifteenth-century source (see Fischer and Lütolf 1972:B IV/3, 334). However, the richest sources for polyphonic settings of Iste confessor are the Trent Codices. In those manuscripts, Iste confessor appears in no fewer than five polyphonic settings: in Trent 87 (No. 148, f. 164) the outer voices are again like those in our Example 4 while the inner voice differs; No. 183 (f. 242v), from the same codex, is different musically from the other version in the manuscript and also from the Dufay settings; in Trent 88, two more arrangements (Nos. 384 and 385, f.240-40v) resemble, but differ in details from, Example 4; and in Codex 92 (No. 1582, f.238) there is a two-voiced adaptation by Dufay which in turn is similar to a copy in Bologna, Liceo musicale, Codex 37, f.322. ${ }^{10}$ This last is also to be found in the works of Dufay (No. 31, p.69) along with another (No.61, p.146) - both are in triple time and share in only some textual features of Example $4 .^{11}$ The many versions of this (monophonic and polyphonic) suggest that there may have been more than just the two melodic traditions (Italian and Dufay) isolated by Ward that can be associated with Iste confessor (1972:184-85). What is certain is that it was better known, more widely distributed, and more frequently used than Letare felix Civitas.

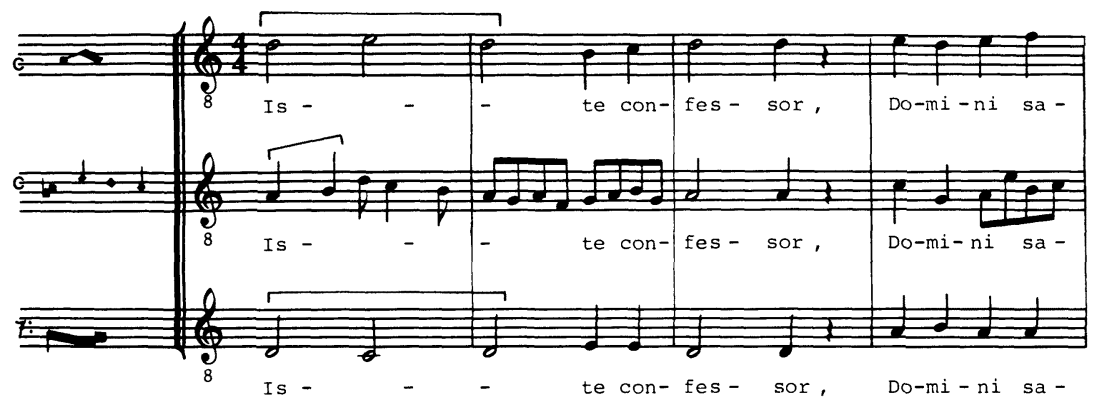



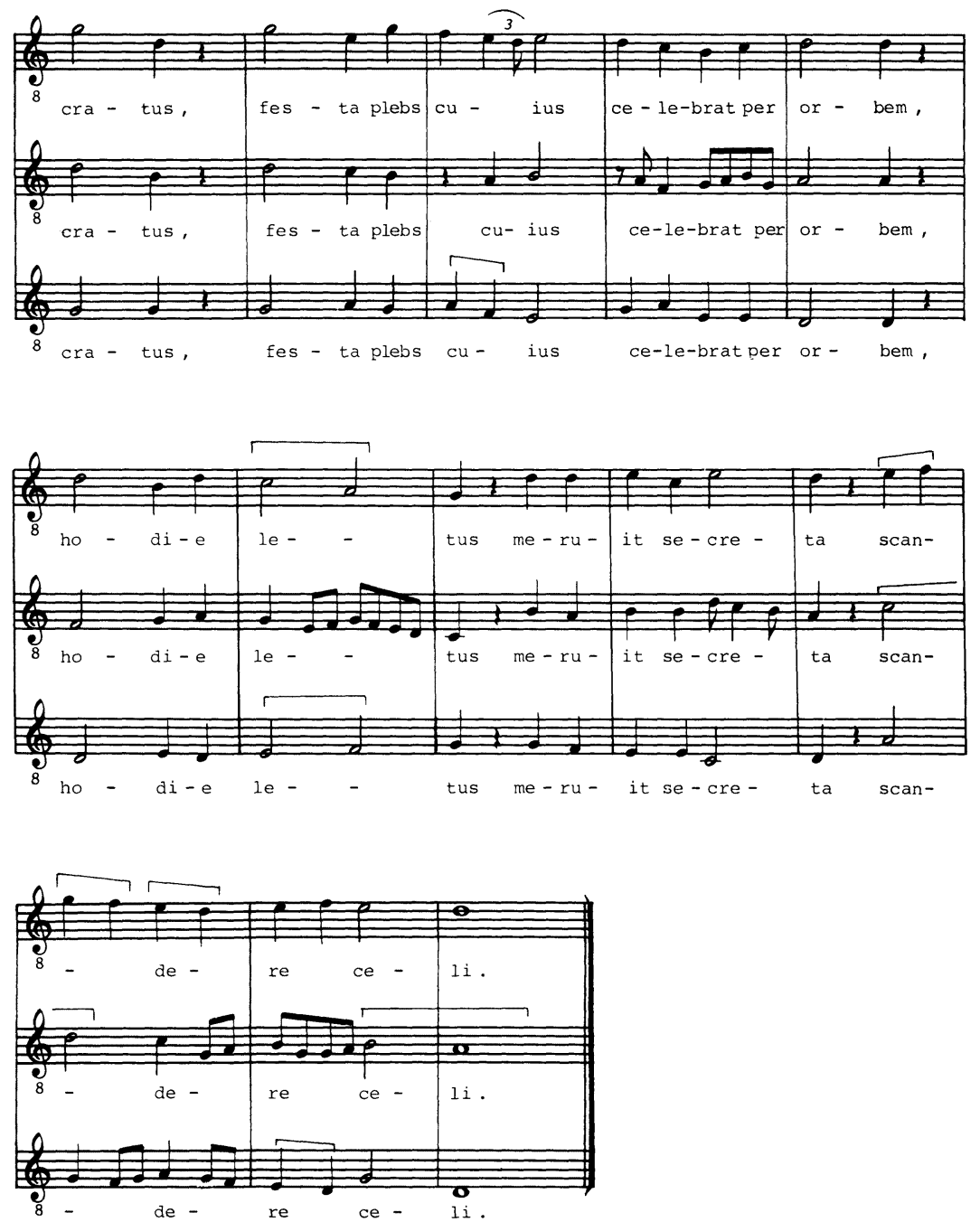

[2. Qui pius, prudens, humilis, pudicus, Sobrius, castus fuit et quietus, Vita dum praesens vegetavit eius Corporis artus.

3. Ad sacrum cuius tumulum frequenter Membra languentum modo sanitati, Quolibet modo fuerint gravati,

Restituuntur.
4. Unde nunc noster chorus in honore Ipsius hymnum canit hunc libenter, Ut piis eius meritis iuvemur

Omne per aevum.

5. Sit salus illi, decus atque virtus, Qui supra caeli residens cacumen Totius mundi machinam gubernat Trinus et unus.] 
The position and importance of Examples 3 and 4, then, differs somewhat, though both at one time may have stemmed from Avignon or composers working there. Example 3 is more esoteric, more independent in its upper voices, more syncopated, and generally more in tune with the ethos of the Ars Nova. Example 4 is a more commonplace, widely distributed hymn, in a simpler style, with only it inner voice serving to "animate" the essentially homophonic character. On the other hand, the text of Letare felix Civitas adopts the standard Ambrosian octosyllabic format while Iste confessor falls in the rarer Sapphic meter (see Apel 1958:424) - a minor paradox since the more popular piece has the less common text. If Example 4 dates from the period of the Apt manuscript, the last quarter of the fourteenth century, then Example 3 would seem to be a mid-century product, that is, one of the earliest polyphonic hymns in existence.

Overall this tiny collection of polyphony from Cividale tells us several things about developments in the late Trecento. The first two pieces inform us about troping processes, the creation of contrafacta, and possible methods of performance for sequences. The other two yield possible insights into the development and uses of the hymn on both peripheral and central levels. All inform us as to the kinds of music introduced and used in the church in Northern Italy and possibly Avignon in the late fourteenth and early fifteenth centuries. As such they constitute an informative microcosm of the greater European sacred musical tradition at the waning of the Middle Ages. 


\section{NOTES}

1. There are diplomatic facsimiles and speculations concerning Examples 1 and 2 in Martinez (1963:130n).

2. See the Liber Usualis, p.372 for an antiphon of the same text but a different melody. Gallo-Vecchi have also published concordances from I-CF41, No.1 and I-CF47, No.1 on their Plates XLII and XXLV.

3. The first six black notes are a third too high. These have been silently emended in Example 1. Also, the D-sharp over "potestas" in the Doxology trope is curious; this is repeated in the concordance in I-CF47.

4. It should be noted that Ia differs from Ib only in its inclusion of an extra note over the word Quem; otherwise it functions as does II.

5. Codex Sangallen 381. For an edition of the text see Analecta Hymnica, XXXIV, p.11. Concordances of the piece from I-CF41 and ICF47 are to be found in Gallo-Vecchi, Plates XLII-XLIV and XLVII-XLIX.

6. It does not appear in the Stäblein collection, The Liber Usualis, in the works of Dufay, the Apt manuscript, or the Trent Codices.

7. For an introduction, see Schoop (1980) and Ward (1980b).

8. The folio number given in RISM is incorrect - it should be 326 .

9. F-Apt 16 bis, f. 16v. For a complete transcription, see Ward (1980a: 841). The piece is cited in RISM B IV/2, 111.

10. For an index of these see Adler \& Koller (1959):35-36; 43; 80.

11. For more sources, see Dufay (1966):xxxi. The transcriptions appear on pages 31 and 61 of the same volume. 


\section{REFERENCES}

ADLER, G. and KOLLER, O.

1959: Sechs Trienter Codice in Denkmäler der Tonkunst in APEL W. Öesterreich. Graz: Akademische Druck-u. verlagsanstalt.

1950: French Secular Music of the Late Fourteenth Century. Cambridge, Mass.: Mediaeval Academy of America.

1958: Gregorian Chant. Bloomington: Indiana University Press. BENEDICTINES OF SOLESMES, eds.

1962: The Liber Usualis. New York: Desclee Co. BUTLER, A.

1963: Lives of the Saints. Edited and revised by $\mathrm{H}$. Thurston and D. Attwater. 4 vols. New York: Kenedy \& Sons.

DREVES, G.M. with BLUME, C. and BANNISTER, H.M.

1886-1922: Analecta Hymnica. 55 vols. Leipzig: O.R. Reisland.

DUFAY, G.

1966: Opera Omnia, $V$, in Corpus Mensurabilis Musicae. Edited by Heinrich Besseler. Rome: American Institute of Musicology.

FAUL, D.

1967: "Donatus" in The New Catholic Encyclopedia. New York: McGraw Hill, IV, 1003.

FISCHER, K. von.

1956: Studien zur italienischen Musik des Trecento und fruehen Quattrocento, in Publikationen der Schweizerischen musikforschenden Gesellschaft, Ser.II,5. Bern.

FISCHER, K. von and GALLO, F.A.

1976: Italian Sacred Music, in Polyphonic Music of the Fourteenth Century. Monaco: Éditions de L'Oiseau-Lyre.

FISCHER, K. von and LÜTOLF, M.

1972: Handschriften mit mehrstimmigen Musik des 14., 15. und 16 Jahrhunderts, in Répertoire internationale des sources musicales, B IV/3 \& 4. Munich: G. Henle Verlag.

GALLO, F. and VECCHI, G.

1968: I piu antichi monumenti sacri italiani, in Monumenta Lyrica Medii Aevi, III,1. Bologna: Università degli Studi di Bologna.

GILLINGHAM, B.

1985: Medieval Polyphonic Sequences. Ottawa: Institute of Mediaeval Music.

GÜNTHER, U.

1980a: "Matheus de Sancto Johanne," in The New Grove Dictionary of Music and Musicians, Stanley Sadie, ed. London: Macmillan, XI:820.

1980b: "Matteo da Perugia," in ibid.: XI:829-31.

1980c: "Sources vii,3," in ibid.: XVII:663-65. The New Grove. 
KELLY, T.F.

1977: "New Music from Old: The Structuring of Responsory Prosas," Journal of the American Musicological Society, 30/3, 366-90.

MARTINEZ, M.L.

1963: Die Musik des Frühen Trecento. Tutzing: Verlegt bei Hans Schneider.

PETROBELLI, PIERLUIGI.

1956: "Nuovo Materiale Polifonico del Medioevo e del rinascimento a Cividale," in Memorie storiche Forogiuliesi, 46, 213-15..

1980: "Cividale del Friuli," in The New Grove Dictionary of Music and Musicians, IV:423.

REANEY, G.

1966: Manuscripts of Polyphonic Music 11th - Early 14th Century. Répertoire internationale des sources musicales, B IV/1. Munich-Duisburg: G. Henle Verlag.

1969: Manuscripts of Polyphonic Music (c.1320-1400). Répertoire internationale des sources musicales, BIV/2. MunichDuisburg: G. Henle Verlag.

SCHERER, B.F.

1967: "St. Donatus of besançon," The New Catholic Encyclopedia. New York: McGraw-Hill, IV:1003.

SCHOOP, $\mathrm{H}$.

1980: "Prepositus Brixiensis," in The New Grove Dictionary of Music and Musicians, XV:216.

STÄBLEIN, B.

1956: Hymnen. Monumenta Monodica Medii Aevi, I. Kassel und Basel: Bärenreiter-Verlag, 1956.

WARD, T.R.

1972: "The Polyphonic Office Hymn and the Liturgy of Fifteenth Century Italy," Musica Disciplina, 25, 161-88.

1980a: "Hymn iii," in The New Grove Dictionary of Music and Musicians, VIII, 841-46.

1980b: "Matheus de Brixia," in ibid.: XI,820. 